\title{
A 'Social form of Knowledge' in Practice: Unofficial Compiling of 1960s Pop Music on CD-R
}

PAUL MARTIN

\section{Setting THe SCEne}

T want to propose that the compiling of obscure 1960s beat, psychedelic and pop records onto compact disc is public history 1 practice. My approach is that public history can be understood as a field of contestation. It can be a way of seeing and questioning the gate keeping role of historical authority rather than a defined discipline in itself. It is also, arguably, about the identification of every day 'moments' where the impact of change is shown to be experienced. Raphael Samuel rightly asserted that history is a 'social form of knowledge'. ${ }^{1}$ Such knowledge, I suggest, is often arrived at through autodidactic enthusiasm or accrued leisure activity experience such as hobbies that inspire a curiosity about the lineage of them and the desire for context and back story to the subject or theme of a collecting interest. The 
individual might typically then join a collecting club or research group to further enlarge and, importantly, share their knowledge. ${ }^{2}$ Jay Winter has stated that public history is essentially a collaborative process ${ }^{3}$ and I would suggest the above complies with this.

Looked at this way, we can recognise the legion of public historians identified by Samuel if we consider history as an activity rather than a profession. ${ }^{4}$ The individual is then an active agent in the discovery, recovery and articulation of history not merely a recipient of academically ascribed authority on the subject. It is within the above discourse that this article is sited. It specifically examines the use of a music technology by sections of the public to make their own historical music meaning rather than subscribe solely to the version marketed by record companies. Echoing Samuel's assertion a decade later, O'Hara and Barry noted about the music industry in 2005 that 'there is a narrow concern [by the music industry] for music consumers as passive audiences for distributed music rather than thinking of consumers as active users of music'. ${ }^{5}$

One of these social practices and active uses has been the utilisation of the Compact Disc Recordable (CD-R) to compile bespoke compilations of historic pop recordings for personal and shared use, principally from enthusiasts own record collections. In this way, I propose, CD-R compiling exemplifies public history as an unofficial social practice.

\section{THE WIDER CONTEXT}

There have been more formal initiatives recently in the conservation and preservation of popular music in Britain that the practice can be sited within. Firstly, Liverpool University's 'Collecting and Curating Popular Music Histories' project, in partnership with National Museums Liverpool, the Victoria and Albert Museum, British Music Experience and the British Library. This project:

engages with the practical and theoretical issues involved with preserving and representing popular music in a museum environment. The project is designed to facilitate knowledge exchange from the museum sector into the university and from the university out to a range of audiences including museum professionals, librarians, archivists, private collectors and the wider public. $^{6}$

Although this looks like a top down approach, it became abundantly clear at the project's symposium held at the British Library in February 
$2011^{7}$ that the majority of speaker's projects were relying on crowd sourcing. Crowd sourcing involves collecting responses from the on-line music consuming public to invitations and questions sent and posed by speakers on blogs, discussion boards and fan sites. Respondents were from the CD-R compiling community. In this way speakers were acting as mediators or gatekeepers for an essentially bottom-up form of history constructing.

The British Music Experience is sited with the 'O2 Bubble' in London. ${ }^{8}$ It is privately funded by global concert promoter Harvey Goldsmith amongst others. Its public display does little more than celebrate the star system: that is, tells the linear story of Britain's pop and rock stars. Behind this though, they do a lot of educational work. They also hosted a debate between the British Phonographic Industry (BPI) and British Pirate Party. ${ }^{9}$

The similarly named but entirely different organisation, The British Music Archive (BMA) holds the closest connection to the social practice discussed below. The BMA's website notes that it:

presents a fascinating insight into an otherwise unheard and untold part of contemporary British history. Our purpose is to salvage, restore and preserve commercially unreleased and culturally significant recorded music [of the 1960s-70s] revealing the stories and people behind it. The original recordings will be freely available both as an online historical archive and as an educational resource. ${ }^{10}$

One of its key aims is: 'To establish and maintain a digital archive for the benefit of the public who themselves are invited to be authors and contribute to the historical content'. ${ }^{11}$

These examples point to an increasing concern with the preservation and dissemination of British pop and rock history for various reasons such as tourism. But it is principally interested in gaining recognition for an ever burgeoning body of unreleased and often provincial artists of the 1960s and early 1970s. Specialist record labels such as Tenth Planet ${ }^{12}$ have been at the forefront of this since the early 1990s, following the lead of Phil Smee who's Rubble series of reissue LPs kick started the British Sixties archiving movemen $t^{13} \mathrm{CD}-\mathrm{R}$ compiling practice, I suggest, is a continuation or another aspect of this. All of this displays a concern with redressing the balance of public awareness of what and who comprised, if not defined the 1960s musically. I have cited the British context as an obvious example. But the practice of 1960s music CD-R compiling is 
global. These document the emergence of scenes and sub-cultures that emerged as a result of the international teen reaction to The Beatles.

In 2007, I placed a questionnaire on three 1960s music related forums to elicit the attitudes and rationale of those engaging in the practice of CD-R compiling, most often on a trade only basis, but sometimes on a very nominal, cost recovery commercial one. I received 16 replies in total from which the samples here are drawn. Whilst not a large cohort, it can be taken as indicative of the type of thinking or attitudes prevalent amongst enthusiasts. This forms the core of this article. I want firstly though to site this practice within a tradition of 'unofficial listening' to embed it within a longer and wider history of unofficial music consumption.

\section{Don't Let Me Be Misunderstood}

In using the term 'official', I mean, firstly, anything legally sanctioned and so officially permitted by law. Secondly, I use it in a public history sense of a dominant or received discourse of history or past event. By 'unofficial' I mean everything outside of these previous definitions and especially, for public history, that which proffers an alternative version to the dominant or received narrative. I have restricted my parameters to the music of the 1960s and its contemporary and continuing reissue because this is the area of my own musical interest. It also demonstrates through the survey results, compiling practice as historical retrieval and reiteration of the past in the present. This is obviously not restricted to any given musical genre or epoch.

The kind of 1960s music the forums surveyed are concerned with cover firstly both British beat groups and American inspired 'garage rock' of the mid 1960s - the US answer to the 'British invasion of beat groups at that time - adolescent enthusiasts aping their idols - such as the Rolling Stones, the Kinks and the Beatles - usually with affected, snarly vocals and fuzz tone guitars as popularised by Keith Richards on the central riff of 'Satisfaction'. Secondly and equally they cover psychedelia of the later 1960s. Although the respondents are largely Anglo-American, the compiling phenomenon as noted above is global. I have written elsewhere about the lenses though which this was interpreted in other countries. ${ }^{14}$

The purpose of all this is firstly to highlight the rapid speed at which the changes in music technology and the concomitant social practice in relation to them happen. Also, how component historical episodes in this process or story can be easily forgotten. Whilst the musical use of the CD-R has been eclipsed to a large degree by today's download culture, it 
is a key facet in the history of the cultural transition of music consumption. One thing public history is about, I suggest, is pointing to such moments before they slip through history's fissures. It would be very easy in the future for the story of pop in the digital age to be told or presented as a seamless, largely unproblematic transition. The digital era is, however, only the latest manifestation of the official/ unofficial discourse on popular music.

Secondly, there is a 'shadow' or unofficial history of pop music consumption, at least since portability in the form of the cassette tape became available. This deserves an article on its own. Both are exemplars of a public history ethos in terms of the 'unofficial' because they have been used to record without official permission and to document that which would otherwise have been musically lost to posterity. Hence, the technically illegal use of cassette tape, for recording live performances for instance, especially when transferred to vinyl or the CD-R has over decades been damned by the music industry as piracy. It has, nonetheless, salvaged and preserved historical moments that would not otherwise have existed in an official version of pop history. ${ }^{15}$

The story of the unofficial production and consumption of recorded music is a patchily documented one. Clinton Haylin's pioneering 1994 book The Great White Wonders - re published in 2004 as Bootleg!: The Rise And Fall Of The Secret Recording Industry on the history of vinyl bootleg LPs - covers the pre-digital analogue recording age in depth. More recently, Lee Marshall's 2005 Bootlegging: Romanticism and Copyright in the Music Industry analyses the affect - largely positive it seems - of bootlegs on the sustainability of an artists' shelf life and the official opposition to them. Marshall defines his three main points about bootlegs as enabling the industry to hold onto a particular type of fan, as underground promotion for both established and upcoming acts and acting as an impetus for a large number of official and successful releases. ${ }^{16}$ Only now, though, with the emergence of organised political pressure groups in the form of the various global 'Pirate Parties', ${ }^{17}$ has a platform for the contestation of the music industry's official narrative emerged.

\section{WE'RE ALL CRIMINALS NOW: LISTENING TO THE 'UNOFFICIAL'}

Mass unofficial music listening in the UK dates back to at least the birth of the British Broadcasting Corporation (BBC) which, having been a private 'company' for five years previously, was established in 1927. At this time it became the monopoly provider of British radio broadcasting. ${ }^{18}$ In introducing the license fee it alienated the pre-existing 
amateur radio experimenter community. In a strikingly parallel attitude to today's music industry, Adrian Johns observes that:

Pirate listeners were incorrigible. They set up receivers without paying license fees, and roamed the ether looking for other signals. Not only did they endanger the public broadcaster by withholding its funding; they were also, it was feared, anarchic in their listening. They might listen in different ways and to different stations... they posed a problem not just of listening, but of knowing about listening. How could an authority gain such knowledge, and how reliable was it once obtained $?^{19}$

Johns continues: 'The problems of experiment and pirate listening became problems at all only because of this decision' to create the BBC as a monopoly broadcaster. ${ }^{20}$ It technically meant that anyone listening to any other station was committing a criminal act. Because radio waves were no respecters of national boundaries this became problematic and the first generation of 'pirate listeners' was active long before the offshore pop pirate radio stations of the $1960 \mathrm{~s}^{21}$

More widely, what was official in most of the west was often unofficial elsewhere. Thus, when 'Beatlemania' struck some countries saw it as a Western propaganda move against their regimes. In Indonesia, Beatle enthused teen groups such as the all-girl beat group Dara Puspita (The Flowers). Group members were arrested and interrogated about their motives. ${ }^{22}$ In Eastern Europe rock ' $n$ ' roll and beat records were copied onto the emulsion on $\mathrm{x}$-ray plates and sold furtively by black market traders. Known originally as 'Roentgenizsat' or 'music on bones' ${ }^{23}$ and later as just 'ribs', it is how western beat music circulated in the Soviet Union in the 1950s to mid 1960s. As Leslie Woodhead, a pioneering documentary maker on the emergent beat scene in the early 1960s, noted:

I heard fantastic tales of how Beatles-starved comrades inscribed bootleg tapes of I Feel Fine into X-ray plates of their Uncle Sergei's lungs - the only vinyl available. I was told how phone boxes across the Soviet Union were vandalised to make pickups for home-made guitars carved from kitchen tables. And serious witnesses professors, reporters, the Russian Deputy Premier insisted that the music and spirit of The Beatles had played a more important role in washing away the 
foundations of totalitarianism than the decades of Cold War propaganda or the threat of nuclear missiles. ${ }^{24}$

In authoritarian regimes globally, pop was deemed unofficial where it had not been vetted. In 1980 the entire limited pressing of Brazilian musical experimenter Lula Cortes's Rose De Sangue LP was seized and destroyed by the military in the north-eastern state of Pernambuco for this reason. ${ }^{25}$ Hence 'unofficial listening' has a wider and longer historical musical context than the present paranoia over copyright infringement. CD-R compiling and trading of obscure historic pop records falls within this wider definition.

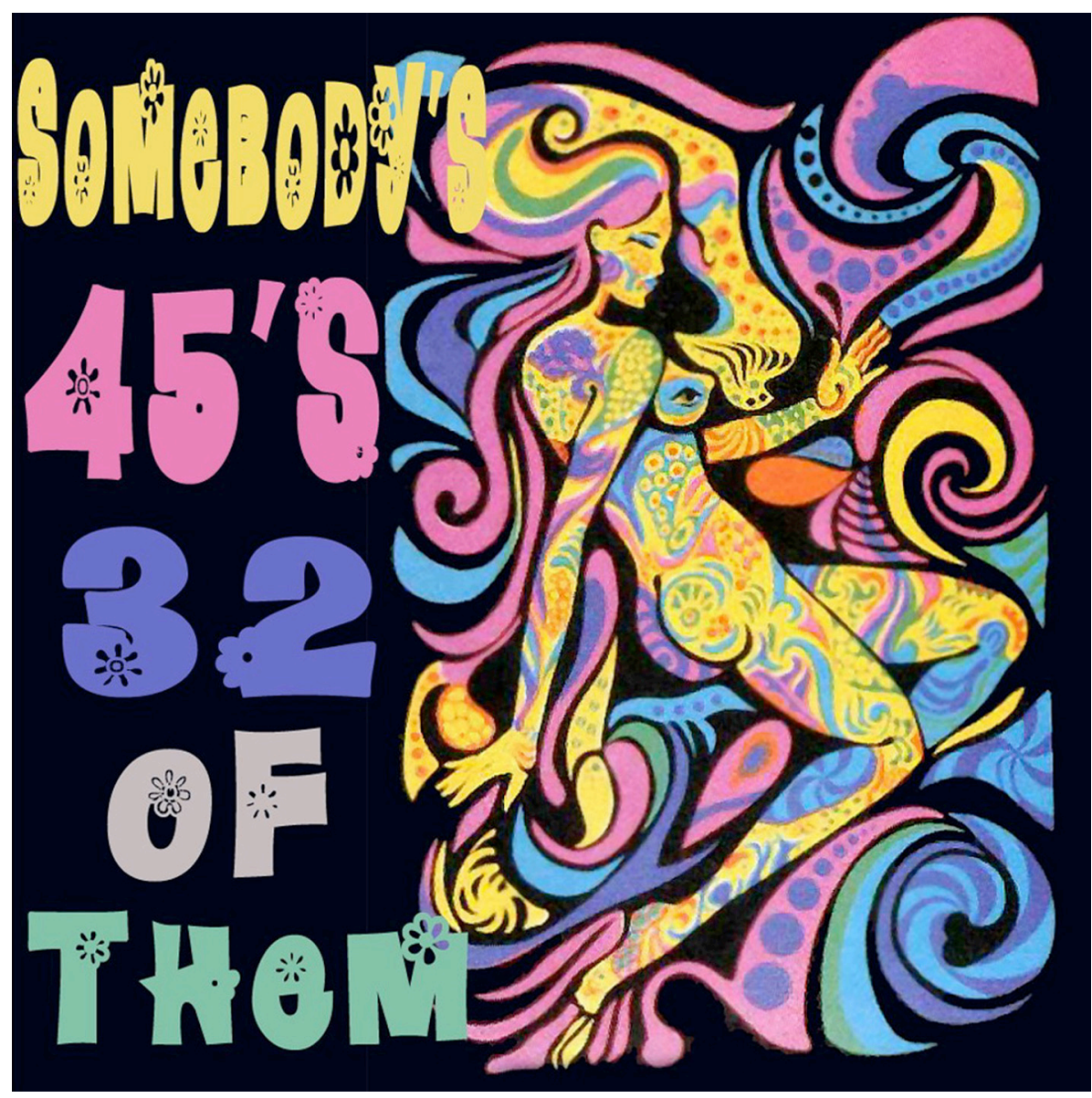

Photoshop enables the creation of some quite beautiful cover art for compilers end results. This one's title tells it like it is! (The author) 
CD-RS: CREATING THE UNOFFICIAL

When the perceived inappropriate use of CD-R by music consumers became the industry's new threat around the turn of the century, it responded with undifferentiated accusations of theft and the resultant impending collapse of the industry. However, as Peter Martin pointed out at the end of 2003 in the Sydney Morning Herald:

The recording industry and its brethren have been crying wolf for years. At various times we have been told that the pianola was going to kill sales of sheet music, that radio was going to kill sales of records, that photocopying would kill sales of books, that the VCR would stop people going to movies, and that cheaper imported records would stop people buying Australian music. $^{26}$

On the one hand, the music industry - for whom the disappearance of a physical format with the advent of downloads suggested a loss of control over the nature of consumption - presented itself as being rendered little more than a licensing agency for its back catalogue. On the other hand, there emerged a consumer base with a youth demographic increasingly growing up in a digitised world where music is available in all sorts of cyber places outside the music industry's regulation (such as blog and torrent sites). Due to the lack of a physical format, many do not view downloading as stealing as the music industry would like them to. A largely older demographic who grew up on physical music formats (principally vinyl) often view the loss of the physicality of their music with disdain (as implied by some survey respondents).

It was even illegal in Britain to upload a legally purchased CD for one's own use to one's own computer hard drive or MP3 player, even though no-one was ever prosecuted for so called 'format shifting'. Most people were oblivious to this. On 3 August 2011 it was announced that the law in Britain was to be changed on the recommendations of the recent Hargreaves report. ${ }^{27}$ Lee Marshall notes that:

the BPI [British Phonographic Institute] (in the UK) and RIAA [Recording Industries Association of America] (in the US) are both private organisations with no obligations except to their members and have no public interest remit. This is much different from their selfpresentation, however, which posits them as a sort of 
quasi-independent industry regulator intended to protect consumer interest. Furthermore the lobbying organisations often imply themselves to be legal watchdogs and this has often resulted in strained relationships with actual police authorities. Both the BPI and RIAA are funded by their members (record labels) and have to justify their costs to the labels. This gives them a vested interest in portraying bootlegging and other forms of piracy, as widespread, economically damaging and defeatable. ${ }^{28}$

One role of a public historian, I suggest, should be to problematise; to find fault with or omission in a dominant or received narrative and take issue with it. It would be simple enough for an unproblematised exhibition or narrative to present MP3 technology, for instance, as an uncontested and linear technological development with Apple's I Tunes as the pinnacle of its expression. However, I Tunes and its peers were only the eventual official response to the rise of unofficial file sharing on the net, the industry's attempt to redefine or legitimise itself in an emergent formatless music consumption environment. ${ }^{29}$ Having discussed some of the issues and history around unofficial listening, I now turn to the survey results where the respondents articulate their own perspectives.

\section{LET ME ASK YOU A QUESTION}

The 2007 questionnaire mentioned at the outset was placed on three 1960s music on-line forums to elicit the attitudes and rationale of those engaging in the practice of CD-R compiling. These were U-Spaces (USA), Garage Punk Forum (USA) and Regal Zonophone (UK). All sixteen responses are in relation to compilations (often abbreviated to 'comps') of 1960s pop or rock music, not of major artists but of very marginal ones in the main. The phenomenon is global and the marginal 1960s pop artists of many countries have been compiled, though, this is often for wider Anglophone collector consumption as many have very minor fan bases in their own countries or for a more geographically widespread ethnic diaspera where the authorities are currently politically indisposed towards them (Iran for instance). ${ }^{30}$ I have coded the respondents simply by respondent number. All are male and typically aged between 35-60 and were either British or American with one respondent from New Zealand and one from Australia. 
I began by asking if owners of CD-R compilations viewed them any differently to 'proper' $\mathrm{CD}$ compilations. A common response was expressed by respondent 1 :

Sonically, 'proper' CDs tend to try for the 'best' sound available and will omit or overlook tracks that should properly be included if a 'clean' copy of the track is unavailable. CD-R's may tend to be more authoritative and historically complete in that they may include a sloppy or sonically horrible version of a track because that's the best version available and to omit the track entirely would be an injustice to the remit of the compilation.

We see here already a public history validation through the concern with a preference for a 'warts and all' inclusion and transparancy. There is a concern here with omission. Essentially, though, the need to know is the driving force, to enable the making of informed evaluation.

Another common response was that expressed by respondent 6 : 'since there are no licensing issues, people who make these collections aren't restricted by what's available or what's in what [record label's] library'. As respondent 15 also noted in relation to his own CD-R compilations: 'Mine are usually better than proper CDs. They're not constricted by style or publishing limitations'. Therefore, the CD-R, like the cassette tape before it, is seen as a platform both to expand on the officially released product and to express one's own creativity or preferences (that is, aesthetic freedom). This second point is born out by respondent 8 who proffered that: 'I actually prefer "home made" collections over commercial releases, they are generally compiled as labours of love and with no eye for profit and therefore are not limited by the constraints of commercialism'. Others such as respondent 16 felt that:

There's room enough in this world for both. I don't think either cannibalizes the other. The home-made compilation obviously doesn't face the myriad hurdles vis-à-vis licensing, etc., which the 'proper' compilers face, but they also don't stand to reap any financial reward the 'proper' compilation publishers get either.

Next I asked if owners listened to their CD-R compilations as much as officially bought ones. 
Respondent 1 reported that they enjoyed listening to the CD-Rs more often because of their lack of constraint in content. Respondent 4 reported that: 'I actually listen to them far more often than legitimate releases because the musical content is on the whole superior to most official releases.' Respondent 8 asserted that: 'they have made it possible for me to hear music that I would never have encountered on official releases and covering genres not deemed profit worthy by the commercial CD manufacturers'. This highlights an important facet of unofficial music compiling: it is primarily used as a means to put obscure and usually un-reissued music into the public domain, albeit at a low level. Historically, in this way the unofficial has caused a buzz amongst a wider record buying public as respondent 15 noted: 'Underground compilations invariably build buzz for unknown records'. This can be to the extent that the unofficial medium has been sanctioned by official reissue, for example in the phenomenon of the 'official bootleg'. ${ }^{31}$

Respondent 10 encapsulated this idea: 'It's not just about music, it's about the story'. Hence, I contend, such activity constitutes historical practice. It is in the best tradition of public history in that it is raising the profile and exposure of hidden or ignored stories and information, often researched on a collective basis. This social knowledge is then articulated via the medium of the CD-R in this instance through social networks such as music forums and blog sites. As Respondent 16 asserted: 'Some of the most beloved compilations in my collection are those which have been compiled by friends and acquaintances whose authority on the subject of their compilation is undeniable, especially after listening to the assemblage.'

I next asked what role such unofficial compilations played in the reissuing of music. Respondent 8 believed that: 'I think they must help. Certainly the circulation of long out of print LPs on CD-R has led to the LPs finally getting official release on $\mathrm{CD}^{\prime}$. Respondent 9 was even more effusive:

It's definitely not a threat to the record industry. I like to think that most of the people that trade CD-R comps will buy 'proper' comps as well, even if it contains lots of songs they already have from old trades. And the fantastic 'Fenton Story' comp started out as a freebie CD$\mathrm{R}$ release, but was later released as a [official] vinyl box [set]. It looks like the same thing might happen to the recent 'G45 Unwaxed' CD-R [later issued officially on vinyl]. This material would never have been available to 
the 'masses' had it not been for the fan who made the CD-R comp.

Respondent 12 observed that: 'I've noticed that many rare 45 s that appeared on home made comps have now appeared on commercial releases. Also [American 1960s] bands like Stone Country and The Stained Glass were poorly served on 'official' comps. Now they have their [own original] LPs re-issued'. Respondent 16 went further in stating that:

I wouldn't be surprised, at all, to read about a compilation in some niche or a single artist overview which has come out because of some well-planted Industry type who happens to be a member of some Forum Group dedicated to a niche or band and begins reading about some hysteria over the discovery of an acetate or what-have-you. (This has probably happened before. I'm just unaware of it.) Fan pressure/clamour can certainly be brought to bear upon a record company though to revisit their back catalogue.

I next addressed the issue of CD-R compiling rather than merely consuming them by asking why the compilation was made? Reciprocation for compilations made for them by others was often cited as with respondent 1 :

it was a proactive sharing environment... almost like inviting a bunch of pals over to listen to $45 \mathrm{~s} . .$. when like minded people get together there is an opportunity to have serious discourse with the most knowledgeable collectors in the world... I also thought that people were sharing something with me and I wanted to give back.

Here we see Samuel's idea of social knowledge and certainly of collaborative effort in practice. Many respondents would not think of themselves as historians or what they do as the practice of history (unless pointed out to them perhaps). As noted at the outset, however, the requirement for a greater knowledge of the subject one practices as a hobby or collects as a tangible object, as in this example, does equate to the practice of historical enquiry and retrieval. Two other reasons were proffered by respondents. Respondent 6 stated that: 'I wanted to get my own un-reissued records onto the format I use most so I could listen to 
them regularly and with the ease that I listen to 'real' [CD] re-issues'. Respondent 9 confessed that: 'I can't really call myself a compiler, since I've never used my own records for the comps I've made, only sound files acquired from blogs, web sites, auctions plus sent to me from collectors'.

CD-R compiling and trading is arguably born variously out of altruism and sociability, which is a trait also noted in collecting ${ }^{32}$ the need to make older formats more usable and portable and to archive or organise stray sound files and MP3s into a meaningful collective whole. In this way, the process of change is revealed. The consumer as an active agent rather than passive recipient, as O'Hara and Barry cited earlier assert, is here demonstrated. Using technological progress in the form of the CD-R to fashion or navigate one's own way forward by incorporating the technology of the past - such as vinyl records or cassette tapes - and virtual networking within this, through web boards, blog sites and discussion forums, creates an alternative musical consumption value system. This is in opposition to the music industry's assumption of the passive consumer model. Thus social knowledge is turned into cultural capital.

Respondent 10 made their collections seemingly from a sense of national exclusion in the 1960s reissue scene: 'I did it because I noted that no one ever mentioned the N[ew] Z[ealand] songs (or Aussie) I remember on any of the [discussion] boards or groups. So I decided to throw together something that would say there was a scene way over on the other side of the world too. Some of the US forums are particularly insular'. Respondent 13 saw themselves as a conduit or gatekeeper between the hidden nature of marginal pop music - that is, which was not commercially successful and largely unheard and a wider audience for it:

[I made compilations] because it amazed me that there were so many non comp[iled] tracks still out there that people hadn't ever heard in 40 years. I felt that people should be able to hear them and I had an unusual position of being the common thread between a lot of people's chaotic collections.

More simply, respondent 14 attested that they made compilations 'to preserve a certain style of music, unavailable altogether before or since'. Respondent 16 stated: 'More often than not I've made them to satisfy a gap in my collection, or as an adjunct to some aspect-genre, niche, specific artist, in which I'm currently researching or obsessing over'. 
A historical, archaeological and taxonomic mindset is clearly disernable in these responses. The emphasis is in one way or another on asserting marginal pop music of the 1960s as a historical and still valid medium in the present. Preservation, historical gap filling and research into this music and its performers are stated motives for compiling unofficial CD-Rs. This all exemplifies the idea of social knowledge and demonstrates it as historical practice consciously pursued as a leisure activity. That they are all interconnected via blog sites, the sharing of private collections and knowledge rearticulated as historical archives digitally placed in the public domain, speaks to the collaborative connectivity that Winter asserts public history practice is often

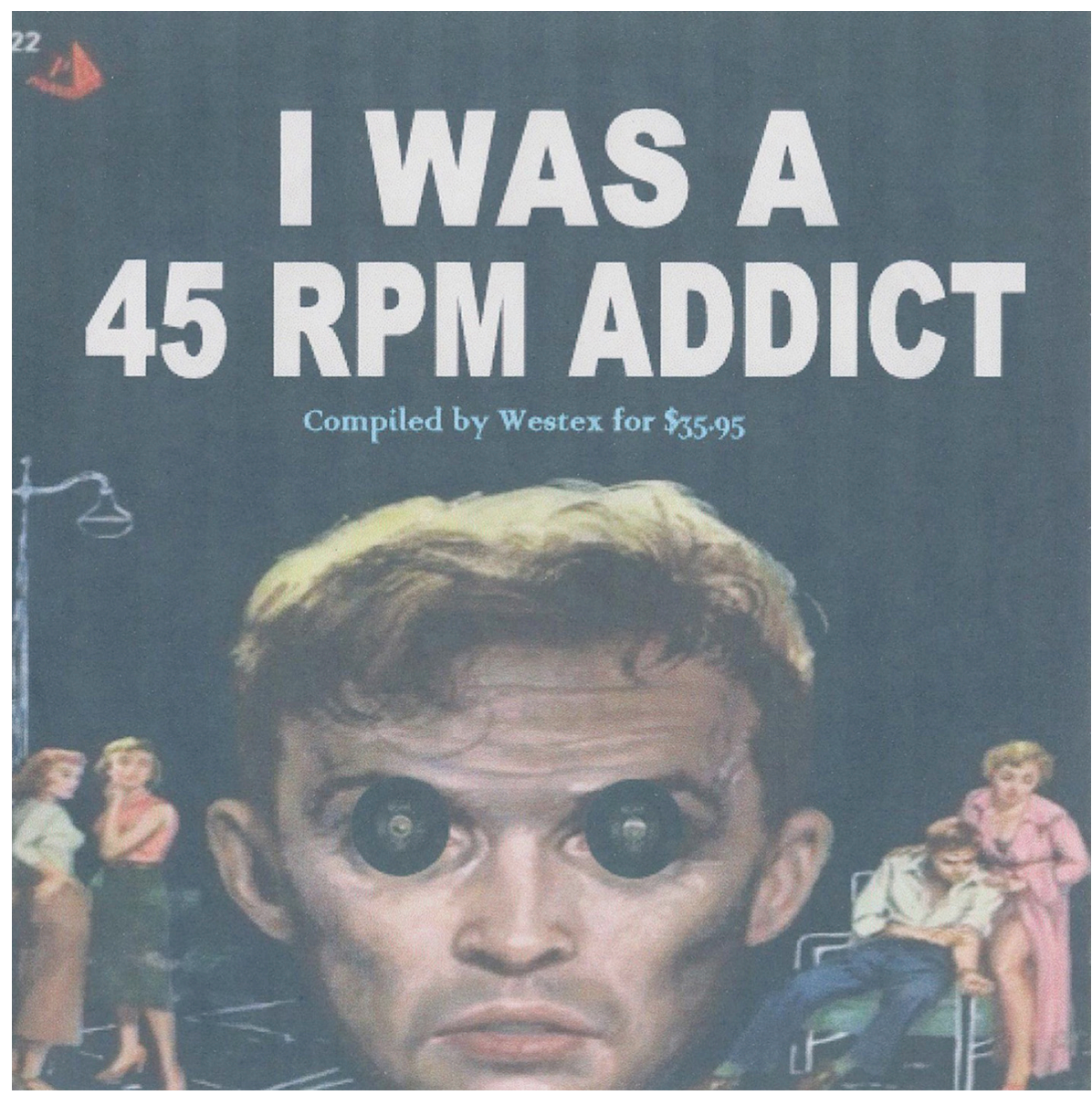

A couple of years ago, the American garage punk forum ran a competition to see who could produce the best 1960s compilation comprised of original $45 \mathrm{rpm}$ singles which in total cost them no more than $\$ 300$ US. This was one of the entries. The prize was a rare garage rock single worth some \$US500 (The author) 
embedded in. ${ }^{33}$ Even if respondents and practitioners generally would not think of themselves as historians as such, their responses to the questionnaire clearly highlights the sense of historical awareness and mission in their activity.

I next asked respondents how they intended to distribute their compilations, such as in trades, give-aways and downloads. The lazy assumption would be that the participants in this survey are just the same people who file share irrespective of the context of the negative consequences the music industry always tells us are inherent in doing so. But this was not the casse with the sample respondents in this survey. Respondent 4, for instance, was concerned with keeping a strict limitation on compilation trading to avoid less scrupulous individuals from file sharing the results. The respondents expressed a kind of militant particularism:

They [the compilation CD-Rs on the Garage Punk discussion forum] were intended as small batch giveaways... there was no financial incentive at all involved... anyone who has incurred the costs of mailings all over the world, packaging, CD-R costs... time involved in sequencing realizes that it's more a labo[u]r of love... the 'spreading of music' thing is the last thing I wanted to become part of... I believe that when the Wyld Canada set by bosshoss [forum contributor] was bootlegged, the era of the forum comp effectively ended... I abhor the file sharing mentality that has harmed the small companies such as Norton, Crypt, Ace/Big Beat by giving away on a worldwide scale songs whose rights have already been paid for... purely selfish... I might add that it just made the forum comp scene go underground... they are still being made, just not being offered to the forum, lol!

This is simplified by Respondent 13 who noted: 'initially [I made my compilations] for trade only, which soon started showing up on Napster and eventually torrents.' Respondent 6 stated that they started making their compilations for themselves but accidentally grew bigger when:

as a graphic artist, [I] started making my own artwork for those things I was transferring for friends and myself. The artwork was coming out so well that I decided to post some of them in my online graphics portfolio. I 
began to get inquiries for the albums so I created a design of a CD catalogue. I had put together a collection of sunshine pop for a friend in Switzerland to thank him for a favour he'd done for me...

This led respondent 6 to:

'accept[ing] donations'. Then I delved further into collecting (via ebay and other Internet vinyl sites) and started making more - for myself and the catalogue. I keep a very low profile and as a result get very few donations but they trickle in. I'd like to do these legit but don't have the necessary start-up funds to acquire licensing and so on... Another friend suggested I present these to record companies and let them worry about the licensing but then I would get nothing for them other than perhaps a one-time fee.

Respondent 12, who also sells their CD-Rs for a very small amount, asserted that:

I only use the best Hi-Fi equipment that I can afford. I don't have a $\$ 4000$ turntable (something that the 'Teenage Shutdown' liners boasted?!?)... But I do have a quality set up with top grade components. I've also recently acquired a $£ 100$ Ortofon mono cartridge. The sonics from this are amazing. Those original 60 s mono 45 s really come to life. I have also acquired the skill and mastering techniques to really get great sonics from a 45 to the digital format without compromising the sound.

Thus in the two instances where CD-R compilations are sold by their creators, this is not the primary reason for making them. The amounts charged $-£ 5$ per disc in the second instance - are mainly to cover the costs of good quality reproduction - and include art work and shell cases. Indeed, in both examples, respondents seem to be justifying their (barely) commercial practice by emphasising the time, effort and care expended on the finished product.

In the main, 'runs' of CD-Rs are always negligible, emphasising the 'companionate' nature of the process. Respondent 8 for instance stated that: 'All my comps were freebies, I gave away maybe 30 copies or more of each CD-R comp I put together'. 
I asked further, what importance did compilers attach to their creations. Responses were nearly all entirely altruistic and were concerned with sharing or spreading their own discoveries with a wider audience. Respondent 4 stated that: 'The importance of these comps is that music that is unavailable for the serious student (sounds stuffy, doesn't it, lol!) of garage rock to own is available to be heard'. For respondent 8 it was: 'all about sharing music on the $\mathrm{CD}$ format that otherwise would only be available to hear on vinyl.' Respondent 10 from New Zealand noted that:

I was trying to get people's interest in some of the really good music that was here. I would love to think people would seek out official releases of the groups because of one song on the compilation. I have done it myself. New Zealand is too small to rely on maybe 20 or 30 psych enthusiasts in our country to make a difference, we need the other collectors in other countries to create a bit of demand.

Respondent 11 noted that:

I probably have enough music to last the rest of my life, and have begun to prepare to move on to some other things. I never intended music collecting to take such a large portion of my time. Still, after I hear many exceptional non-comped tunes accumulate I feel an obligation to let others hear them, especially arranged in a knockout way, with only great stuff back to back.

The 'labo[u]r of love' motivation was often repeated in responses as an expression of altruism as were intimations of an educational role through the spreading of 'knowledge' and in preservation. Respondent 13 said the practice was: 'Generally a labo[u]r of love, since the effort in assembling these was pretty heavy'. Respondent 14 mentioned:

'Preservation of music which otherwise would be lost. Also important is an amount of knowledge of how to arrange the songs and which bits fit together to make a playable collection within the scope of the release'. Respondent 15 reported: 'It's one of my favourite ways to learn about new old music!' Perhaps this is most poignantly expressed by Respondent 16: 
The importance attached to them is in the labo[u]r of love in which they're assembled. When I assemble my own I typically have a focus... so it satisfies a desire on my part to bring into perspective a genre or niche or a band/artist's career as an overview. Usually borne out of some cloud of unknowing on my part, it's an attempt to shine a light on this unknown. The importance is intrinsic not extrinsic. I gain, nor would I ever, nothing financially. More often than not it ends up costing me just to assemble the various pieces of the puzzle I'm focusing on.

Thus key motivations in creating and making available bespoke CD-R compilations in this sample include altruism - through sharing the music - education - through sharing knowledge and information historical and archaeological awareness - through reclamation and preservation of marginal 1960s pop records, typically though flea markets, thrift stores, record fairs and the internet. This is also the case in the two instances where there was a confessed nominal profit being made. Respondent 6 stated:

I have been collecting records since the mid-60s. I am also a songwiter/singer who hasn't had too much success and I can't afford to make my own music on a regular basis. This is a great outlet for creativity and discovery. Since I keep such a low profile, I don't rake in the dough by any means. I don't want to be slapped with a cease and desist for the reason that I think this stuff deserves to be shared. I put a lot of work into it so I don't think asking for donations is asking too much.

Respondent 12 argued that:

My comps are important to me because I know they sound great and many of the $45 \mathrm{~s} . .$. would have no chance of ever being unearthed in my lifetime. I also feel that these rarities should be digitized for the modern age otherwise they could be lost and forgotten about forever. I'm not bothered about the money I may make from a comp of mine. After I've spent hours of my time remastering, designing a cover, writing and researching liners, using my ink and photography paper to print the covers, paying ebay or Paypal fees etc etc I'll probably 
make $£ 2$. I just think it's fair to get a little something for all of my trouble for making the music available or improving previously compiled things.

Overall, the respondents speak to a public history impetus to make the forgotten remembered; their practice concerns the historical renovation of omission. Essentially, this effectively uses marginalised 1960s pop records to contextualise the iconic status of 1960s pop stars in showing the wider musical and music industry arena from which they all emerged and the reasons why some did not make it.

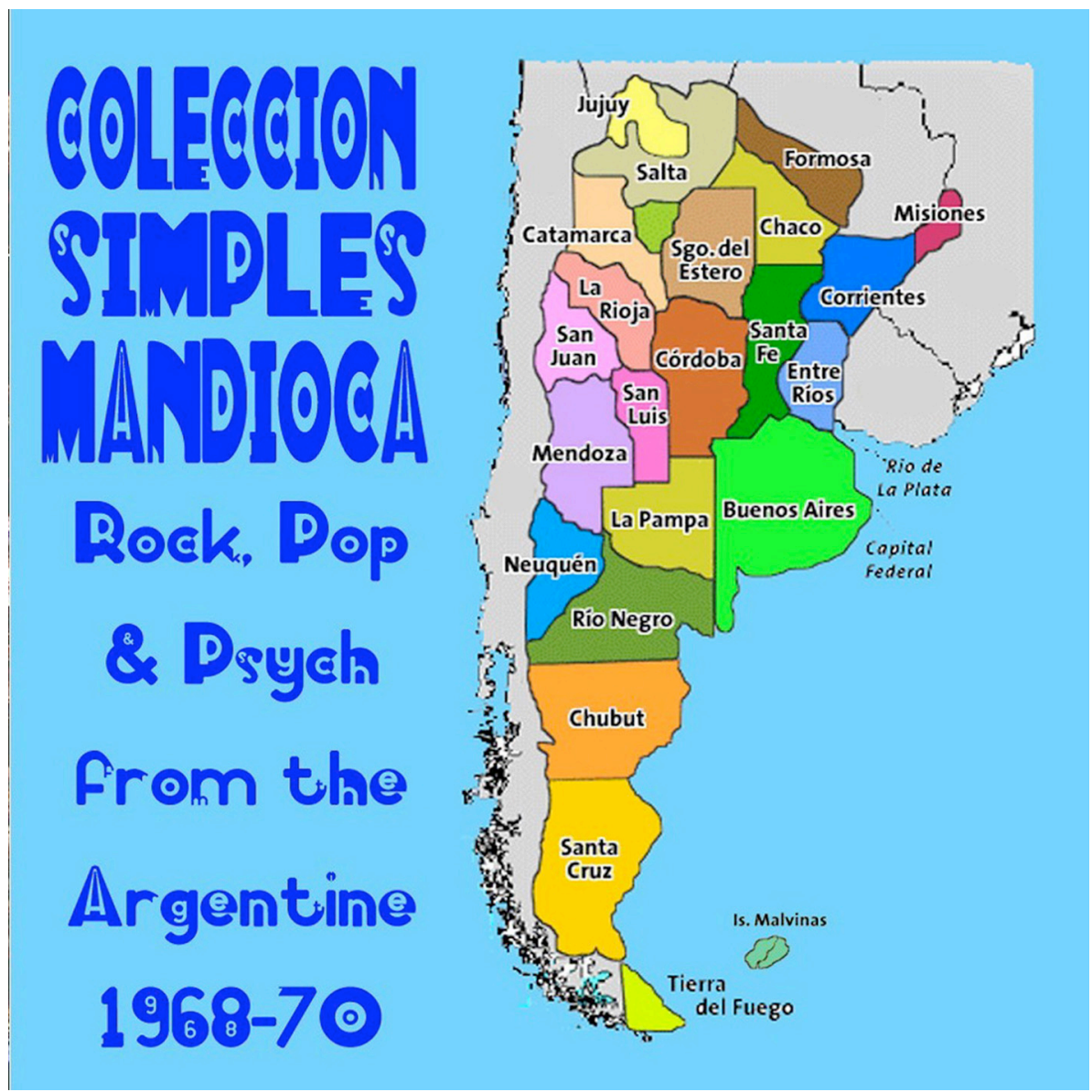

The coming of the internet infinitely widened and deepened the exposure of indigenous expressions of 1960s pop music across the world. To the extent that in the 2000s, people have the potential to hear a vastly wider selection of 1960s popular music than anyone did in the sixties (The author) 


\section{THE FINAL TRACK}

I began this article by suggesting that CD-R compiling of obscure vintage pop records represented the practical application of historical social knowledge. As survey respondents demonstrated, collaboration, reciprocation and the sharing of knowledge are enmeshed in this practice of historical music recovery. This speaks to Winter's point that public history is essentially collaborative and, further, to both Samuel's and O'Hara and Barry's contentions about individuals being active agents in history making rather than passive recipients. Survey respondents variously implied or overtly stated that they did not see themselves as opposing the official commercially made reissue compilations of 1960s music. Rather, they felt there were inevitably omissions or silences within them, which their own practice helped to rebalance.

The music industry's disingenuous blanket assertion that all copying is simply piracy irrespective of any altruistic, historical or noncommercial motivations, is a dominant narrative in the media. ${ }^{34} \mathrm{In}$ exploring the practice of $\mathrm{CD}-\mathrm{R}$ compiling I have presented it as a means of dissemination of historical musical social knowledge. In so doing, I have sought to problematise the music industry's official narrative and site the practice within the framework of public history construction.

Public historians should be in the business of problametising representations of the past. I suggest that is what CD-R compilers are doing here within the lineage of social knowledge and unofficial listening cited by Adrian Johns earlier in relation to 'pirate listeners' and the BBC of the 1930s. Public history is also about the identification and analysis of 'moments'. The use of CD-R for compiling is such a moment in that it emerged, as a replacement for the personal computer floppy disc, in tandem with the internet as a 'place' for disseminating and consuming pop music and is now itself a format nearing the precipice of obsolescence given the wide use of memory sticks and portable hard drives. Survey respondents themselves have validated this moment in their observations. They expressed their opinions on their values in their unofficial activity as essentially those of historical investigators and salvagers, using the CD-R format to log their findings. This use of the $\mathrm{CD}-\mathrm{R}$ then renders it a historical document. Unofficial listeners are also official consumers and negotiate their own constructivist, historical musical meaning and understanding through engagement with the whole as active users. 


\section{ENDNOTES}

My thanks to Hilda Kean, Paul Ashton and two anonymous referees for reading drafts of this paper and for their helpful suggestions.

${ }^{1}$ Raphael Samuel, Theatres of Memory: Past And Present In Contemporary Culture, Verso, London, 1994, p8.

${ }^{2}$ See, for example, Paul Martin, Popular Collecting and the Everday Self: the reinvention of museums, Leicester University Press, Leichester, 1999, pp67-98.

${ }^{3}$ Jay Winter, 'Public History and Historical Scholarship', History Workshop Journal, no 42, Autumn, 1996, pp169-173.

${ }^{4}$ Samuel, op cit, p17.

${ }^{5}$ Kenton O'Hara and Barry Brown (eds), Consuming Music Together: Social and Collaborative Aspects of Music Consumption Technologies, Springer Books, Netherlands, 2006, p4.

${ }^{6} \mathrm{http}: / /$ www.liv.ac.uk/music/research/projects.htm (accessed 18 December 2011).

7 Collecting and Curating Popular Music Histories symposium, Foyle Suite, British Library, Tuesday, 5 July 2011.

${ }^{8}$ http://www.britishmusicexperience.com/ (accessed 18 December 2011).

${ }^{9}$ Education officer, The British Museum Experience, conversation at symposium 5 July 2011.

${ }^{10} \mathrm{http}: / / \mathrm{www}$. britishmusicexperience.com/ (accessed 18 December 2011).

11 ibid.

${ }^{12}$ http:/ / tenthplanet-woodenhill.co.uk (accessed 18th December 2011)

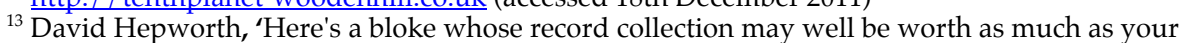
house', podcast, http://www.wordmagazine.co.uk/content/podcast-with-a-man-whoserecords-are-worth-much-your-house-probably. See also Brian Neavyn, 'Bam-Caruso, Rubble \& Freak Beat', Ugly Things, no 32, Fall/ Winter 2011, pp36-37.

${ }^{14}$ Paul Martin, 'Can You Feel The Beat?: compiling and reissuing marginal pop music of the 1960s', Hard Times, no 88, December 2010, pp15-19.

${ }^{15}$ See for example Scream Loud!!!: The Fenton Story, 3xLP; 2xCD set, Wayback Recrods, 2006 see http:/ / www.ugly-things.com 1960s database; Unissued Garage Acetates vols 1-5 LPs, Norton Records, USA. Available www.nortonrecords.com (accessed 29 July 2011). All began as private CD-R compilations.

${ }^{16}$ Lee Marshall, Bootlegging: Romanticism and Copyright in the Music Industry, Sage, 2005, p136.

${ }^{17}$ See for example, the British Pirate Party. Available http://www.pirateparty.org.uk/ (accessed 18 December 2011).

${ }^{18}$ Adrian Johns, Death of a Pirate: British Radio and he Making of the Information Age, W.W. Noton \& Co, London, 2010, p30.

${ }^{19}$ ibid, p35.

${ }^{20}$ ibid, p36.

${ }^{21}$ ibid, pp13-36.

${ }^{22}$ Steven Farram, 'Wage War Against Beatle Music!: Censorship and Music in Soekarno's Indonesia', Review of Indonesian and Malaysian Affairs, vol 41, no 2, 2007, pp247-277. Cited by Alan Bishop in liner note booklet for Dara Puspita 1966-1968 CD, Sublime Frequencies Records, USA, 2010, p.5. Available

http:/ / www.sublimefrequencies.com/item.asp?Item id=65\&cd=Dara-Puspita-1966-1968 (accessed 29th July 2011).

${ }^{23}$ Timothy W. Ryback, Rock Around the Bloc: A History of Rock Music in Eastern Europe and the Soviet Union, Oxford University Press, Oxford, 1989, pp32-33.

${ }^{24}$ Leslie Woodhead, 'How The Beatles Rocked The Kremlin'. Available http://www.bbc.co.uk/blogs/bbcmusic/2009/09/how the beatles rocked the kre.html (accessed 29 July 2011). See also Leslie Woodhead, 'How The Beatles Rocked the Eastern Bloc', BBC Mobile news magazine. Available http:/ / news.bbc.co.uk/1/hi/magazine/8232235.stm (accessed 29 July 2011); Leslie Woodhead, 'How The Beatles Rocked The Kremlin' documentary, Storyville, broadcast on BBC4, UK, 7 September 2010.

${ }^{25}$ David Buttle, historical liner notes for Psychedelic Pernambuco 2xLP, CD, Mr Bongo Records, issued July 2011.

${ }^{26}$ Peter Martin, 'Forget the spin, taping is not killing music', Sydney Morning Herald, 31 December 2003. Available

http:/ / www.smh.com.au/articles/2003/12/30/1072546532286.html (accessed 29 July 2011). See also, Peter Martin, 'Ditch the spin. It's a record-sales record!', Tuesday Column, Sydney Morning Herald, 31 March 2008. Available http:// www.petermartin.com.au/2008/03/tuesday-column-ditch-spin-its-record.html 
and the many interesting comments below the article itself. (Accessed 29 July 2011.)

${ }^{27}$ Harry Wallop, 'Millions of iPod fans breaking law by copying CDs', The Telegraph, 24 February 2010, available

http:/ / www.telegraph.co.uk/technology/apple/7299505/Millions-of-iPod-fans-breakinglaw-by-copying-CDs.html accessed 29 July 2011. Anon, 'Out of touch and out of date: Law against copying CDs to be ditched', Daily Mail, 19 May 2011. Available

http:/ / www.dailymail.co.uk/news/article-1388419/Out-touch-date-Law-copying-CDs-

ditched.html accessed 29 July 2011; Ben Cardew, 'Hargreaves report: industry responds on IP recommendations', Music Week, 23 May 2011. Available

http: / / www.musicweek.com/ story.asp?storyCode $=1045299 \&$ sectioncode $=1$

accessed 29 July 2011

Ian Dunt, 'With one stroke, Cable stops millions breaking the law'. Available

http:// www.politics.co.uk/news/2011/08/02/ with-one-stroke-cable-stops-millionsbreaking

accessed 3 August 2011.

${ }^{28}$ Marshall, p139.

${ }^{29}$ Roy Shuker, Wax Trash and Vinyl Treasures: Record Collecting as a Social Practice, Ashgate Publishing, Farnham, Surrey, 2010, pp76-80 ; Maria Styvern, 'The Intangibility of Music in the Internet Age', Popular Music and Society, vol 30, no 1, pp53-65.

${ }^{30}$ Martin, 'Can You Feel The Beat?'.

${ }^{31}$ Historic examples include Bob Dylan, The Grateful Dead and Pearl Jam.

${ }^{32}$ Russell Belk and Melanie Wallendorf, 'Of mice and men: gender identity in collecting', Susan M. Peace (ed), Interpreting Objects and Collections, Routledge, London, 1994, pp245-246; Martin, op cit, pp79-86.

${ }^{33}$ Russell Belk and Melanie Wallendorf, 'Of mice and men: gender identity in collecting', Susan M. Peace (ed), Interpreting Objects and Collections, Routledge, London, 1994, pp245-246; Martin, op cit, pp79-86.

${ }^{34}$ Giles Tremlett, 'Spanish court rules free music downloads are legal for own use', The Guardian, 3 November 2006. Available

http://www.guardian.co.uk/technology/2006/nov/03/news.spain accessed 29 July 2011. 